\title{
KARST SPRINGS AS HABITATS FOR RARE AND PROTECTED PLANT SPECIES: A NEW INLAND LOCALITY OF A HALOPHYTE PLANT BATRACHIUM BAUDOTII (RANUNCULACEAE) IN A KARST SPRING IN CENTRAL EUROPE
}

\author{
Krzysztof SpaŁeK ${ }^{1}$ And JarosŁaw ProćKów²
}

\begin{abstract}
A new inland locality of Batrachium baudotii was discovered in a karst spring in Central Europe; the species had not been reported from such habitats previously. The locality is situated more than $400 \mathrm{~km}$ away from the Baltic coast and about $120 \mathrm{~km}$ northwest of the only previously known Polish inland locality; both sites are outside its continuous range and are two of the four easternmost in Central Europe. In the eastern part of its range, Batrachium baudotii is very rare and is protected or red-listed in these areas. The main goal of this paper is to draw attention to the karst springs' flora, with some interesting and rare species that can be found there. Within the examined patches, no other saline taxa were recorded. The data show that the species prefers habitats in the zone of discharge of karst waters from Jurassic, Cretaceous, and Triassic water-bearing strata. The locality should be especially protected and constantly monitored.
\end{abstract}

\section{INTRODUCTION}

Springs are among the most valuable components of the European landscape. Because of their generally small size and marginal economic importance, they are very little studied (Kucharski, 2007). Springs develop a specific vegetation because the subterranean water reaching the surface usually has a relatively constant temperature throughout the year of about $9{ }^{\circ} \mathrm{C}$ (Lindacher, 1995; Zarzycki et al., 2002). In Poland, springs harbor many interesting and rare plant species and communities (Kucharski, 2007; Spałek and Horska-Schwarz, 2009; Spałek et al., 2011).

The brackish water-crowfoot (Batrachium baudotii) is found in nearly all of Europe, except northern Scandinavia north of $65^{\circ} \mathrm{N}$, and in northwestern Africa. It usually occurs along the coast, in salt water, at depths of 0.5 to $1.5 \mathrm{~m}$ on sandy and muddy bottoms (Hocquette, 1927; Braun-Blanquet, 1952; Klement, 1953; den Hartog, 1963; Cook, 1966; Westhoff and Held, 1969; Géhu and Mériaux, 1983; Birse, 1984; Wegener, 1991; Passarge, 1992, 1996; Pott, 1995; Schubert et al., 1995; Rodwell, 1998). It is also frequent in estuaries and on islands. In Poland, it is known from a few localities along the Baltic coast (Zajac and Zajac, 2001). Within the whole of its range, it is very rare in inland fresh waters, found only where the water is stagnant or slow-flowing, usually over a calcareous substratum. A few inland localities are known from France, Austria, Germany, the Czech Republic, Slovakia, and Hungary (Husák et al., 1982; Jasiewicz, 1985; Hultén and Fries, 1986; Husák and Procházka, 1999; Samková, 1999; Holub and Procházka, 2000; Kaplan, 2005, 2008; K. Šumberová and A. Mesterázy, pers. comm.) and, till now, only one isolated locality from Poland, the Będkowska Valley, near Kraków (Jasiewicz, 1985; Zając and Zając, 2001).

It should be pointed out that in the eastern part of its range Batrachium baudotii is particularly rare, known only from scattered localities. For this reason, in some countries, including Poland, it is legally protected and is included in the Red List of Plants of Poland with the E category $(=C R)$, i.e. declining - critically endangered (Zarzycki and Szelagg, 2006). It is also very rare and critically endangered in the Czech Republic (Holub and Procházka, 2000), while in Slovakia it is classified as an endangered species (EN) (Feráková et al., 2001). In Hungary, it is a rare species and is included in the NT category, i.e., near threatened (Király, 2007).

In the literature, there are no detailed data on the physical-chemical properties of waters and substrata in the habitats of the species, especially in its inland localities. The knowledge of such parameters is essential for effective protection of its localities (Spałek et al., 2011). At sites in the Czech Republic, the species finds its optimum in lowland flooded sand pits at succession stages in which the water already contains enough nutrients, but is still not too eutrophic and muddy (Samková, 1999; Kaplan, 2005, 2008). The localities are situated within the warmest regions of the Czech Republic, and they are formed by basic bedrocks (K. Šumberová, pers. comm.). In Hungary,

\footnotetext{
${ }^{1}$ Laboratory of Geobotany \& Plant Conservation, Department of Biosystematics, University of Opole, ul. Oleska 22, PL-45-052 Opole, Poland kspalek@uni.opole.pl ${ }^{2}$ Department of Biodiversity \& Plant Cover Protection, Institute of Plant Biology, Wrocław University, ul. Kanonia 6/8, PL-50-328 Wrocław, Poland jprockow@ biol.uni.wroc.pl
} 
some localities are situated in gravel pits (A. Mesterázy, pers. comm.).

Based on literature data in Great Britain, both saline (Zannichellia palustris subsp. palustris) and freshwater (Ceratophyllum submersum, Potamogeton pectinatus, Ruppia maritima, Callitriche stagnalis, C. obtusangula, C. platycarpa, Riccia fluitans, Lemna trisulca, L. minor, L. gibba, and Ceratophyllum demersum) taxa co-occur in patches with Batrachium baudotii (Rodwell, 1998). The situation is similar in Germany: Ruppia cirrhosa, Zannichellia palustris subsp. pedicellata, Potamogeton pectinatus, and P. pusillus (Klement, 1953; Wegener, 1991; Passarge, 1992, 1996; Pott, 1995; Schubert et al., 1995). The main goal of this paper is to draw attention to the karst springs' flora, with some interesting and rare species which can be found there, even including saline taxa (e.g. Batrachium baudotii) that had not been reported from such habitats to date.

\section{Methods}

The fieldwork was conducted during the growth seasons in 2008-2009. The species names of vascular plants follow Mirek et al. (2002). The physical and chemical properties of the habitat were assessed in the field, when the $\mathrm{pH}$ of the water was measured in the spring at depths of 0 to $20 \mathrm{~cm}$ and 20 to $70 \mathrm{~cm}$, on March 17, 2008 and June 23, 2009. Measurements of conductivity, water temperature, and $\mathrm{O}_{2}$ content were taken at the depth of 0 to $20 \mathrm{~cm}$ at the spring and at the zone of its flow into the river with a CX 401 Elmetron multipurpose measuring device. Samples of water at the depth of 0 to $70 \mathrm{~cm}$ and samples of the bottom sediments were collected from the spring. Laboratory tests included analysis of the water, with measurements of $\mathrm{CO}_{2}$ content $\left(\mathrm{mg} \mathrm{dm}{ }^{-3}\right)$, general alkalinity (titration), $\mathrm{SO}_{4}^{2-}\left(\mathrm{mg} \mathrm{dm}^{-3}\right)$ (turbidimetric method), $\mathrm{NO}_{3}^{-}, \mathrm{Cl}^{-}, \mathrm{NH}_{4}^{+}, \mathrm{PO}_{4}^{3-}\left(\mathrm{mg} \mathrm{dm}^{-3}\right)$ (colorimetric method with a Slandi LF 2004 spectrophotometer). Bottom sediments were also analyzed, with $\mathrm{pH}$ measurements of the water extract (potentiometric method used in soil sciences) and $\mathrm{CaCO}_{3}$ content $\left(\mathrm{mg} \mathrm{dm}{ }^{-3}\right.$ ) (calicimeterpressure method).

\section{Results AND Discussion}

During our geobotanical research in Poland, a new inland locality of Batrachium baudotii was discovered in a karst spring in the village of Rożniatów near the town of Strzelce Opolskie in Silesia, southwestern Poland (Fig. 1); the species has not been reported from such habitats previously. The site is situated more than $400 \mathrm{~km}$ away from the Baltic coast and about $120 \mathrm{~km}$ northwest of the only previously-known Polish inland locality, in the Becdkowska Valley near Kraków (Fig. 1). So both Polish inland sites of $B$. baudotii are outside its continuous range and are two of the four easternmost in Central Europe. (The more eastern localities are in Slovakia: Chrámec, Ipel'sko-

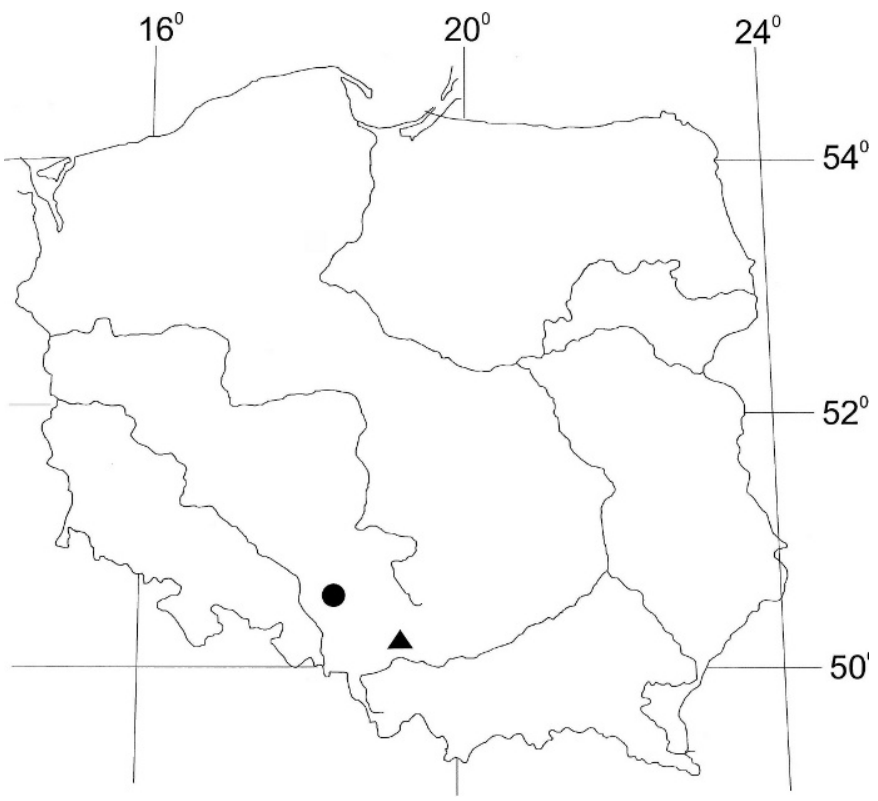

Figure 1. Inland localities of Batrachium baudotii (Ranunculaceae) in Poland (black circle - a new locality in a karst spring in the village Rożniątów, near the town of Strzelce Opolskie, Silesia; black triangle - the previously known Polish inland site in the Będkowska Valley, near Kraków).

rimavska brázda, and Bol’, Potisí [Husák and Procházka, 1999]).

The plant covered 0.2 ha in 2008 and 0.3 ha in 2009 (Figs. 2-3). The accompanying taxa were Callitriche hamulata, Veronica beccabunga f. submersa, Berula erecta f. submersa, Potamogeton pectinatus, Callitriche verna, and Lemna minor. So no saline taxa were found within Batrachium baudotii phytocoenoses (Spałek et al., 2011).

The spring in Rożniatów is located in the village center (Assmann, 1929; Staśko, 1984, 1992; Horska-Schwarz and Spałek, 2008). The subterranean waters emerge at an elevation of 231-232 m (Staśko, 1992; Spałek et al., 2011). Waters in the spring zone are characterized by neutral and slightly alkaline $\mathrm{pH}$ : the mean $\mathrm{pH}$ is within $7.0-7.4$. The water temperature is in the range $8.8-11.5^{\circ} \mathrm{C}$. The analyses showed that the water is dominated by the ions $\mathrm{HCO}_{3}^{-}$, $\mathrm{Ca}^{2+}$ and $\mathrm{Mg}^{2+}$; also confirmed is the presence of $\mathrm{SO}_{4}^{2-}$, $\mathrm{NO}_{3}^{-}, \mathrm{PO}_{4}^{3-}$ and $\mathrm{Cl}^{-}$ions. Based on the total content of dissolved mineral components, the water was classified as moderately mineralized (Spałek et al., 2011). At present, the spring contains fine sediment of slightly alkaline $\mathrm{pH}$ (7.5). The sediment at the confluence with the river has a slightly lower $\mathrm{pH}$ (6.98). It should be added, however, that during 1986-1988 the bottom was artificially cleaned (Staśko, 1984, 1992). The analysis of the deposits in 2009 showed that they were rich in $\mathrm{Ca}, \mathrm{Mg}, \mathrm{Al}, \mathrm{K}$, and $\mathrm{Na}$. The heavy metals $\mathrm{Zn}, \mathrm{Mn}, \mathrm{Cu}$, and $\mathrm{Cd}$ occurred there in smaller quantities. At the river, the sediments also contain $\mathrm{Pb}$, which was not detected in the spring zone. Detailed results

Journal of Cave and Karst Studies, December 2011 159 

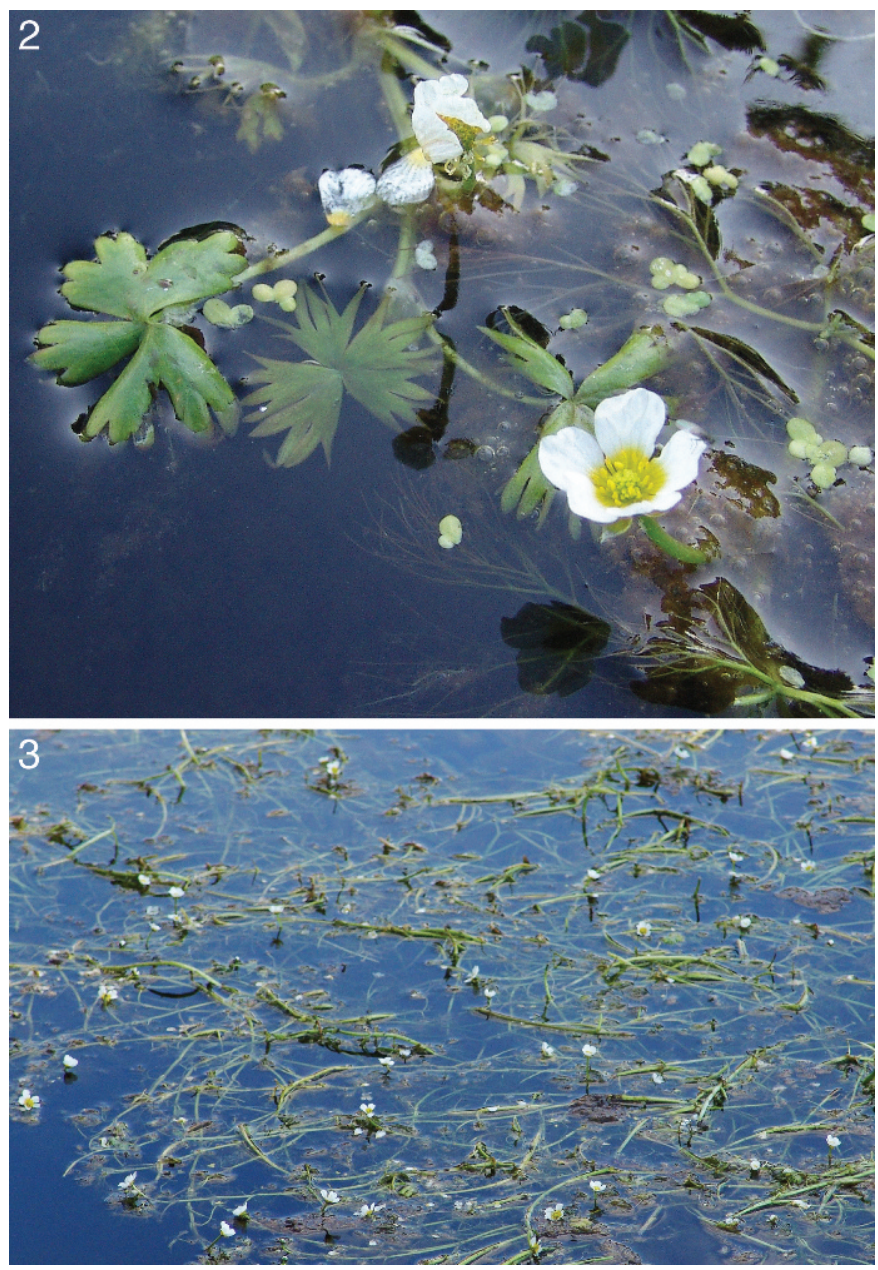

Figures 2 - 3. Batrachium baudotii (Ranunculus baudotii) in the karst spring in Rożniątów village.

of laboratory analysis of the water and bottom deposits for the locality are contained in Spałek et al. (2011).

The similar character of subterranean waters in these sites $\left(\mathrm{HCO}_{3}-\mathrm{Ca}\right.$ and natural content of $\mathrm{SO}_{4}$, associated with the occurrence of intercalation of anhydrite and gypsum in the substratum), shows that the species prefers habitats in the zone of discharge of karst waters from Jurassic, Cretaceous, and Triassic water-bearing levels (Kryza and Staśko, 2000; Macioszczyk and Dobrzyński, 2002; Kryza and Kryza, 2003, 2006; Spałek et al., 2011). However, the absence of localities of this species in other springs of similar chemical composition shows that its occurrence is also affected by an array of other characteristics of the source: bottom morphology, properties of bottom sediments, substratum $\mathrm{pH}$, water temperature, salinity, spring discharge, and the level of human disturbance. It should be pointed out that at present, with such great pressure from the surroundings, the new locality of Batrachium baudotii within the spring area in Rożniątów is exposed to considerable stress, and so it should be especially protected and constantly monitored.

\section{ACKNOWLEDGEMENTS}

We wish to thank Dr. Richard Hrivnak (Slovak Academy of Sciences, Bratislava), Prof. Stanisław Staśko (Institute of Geological Sciences, Wrocław University), and Dr. Sylwia Horska-Schwarz (Institute of Geography \& Regional Development, Wrocław University) for their cooperation, Dr. Attila Mesterázy (Hungary) for making his unpublished data available to us, and Dr. Kateřina Šumberová (Institute of Botany of the Academy of Science of the Czech Republic, Brno) for the floristical and ecological data from Moravia and Bohemia. Special thanks go to Mr. Jason Schock (Department of Applied Linguistics, Institute of English Studies, Wrocław University), who kindly improved our American English.

\section{REFERENCES}

Assmann, P., 1929, Über die Enstehung der Quelle des Rosniontauer Wasser un der sogenanten Quelle von Suchau: Naturkundl, Kolonowska, Basteine aus Osterschlesien.

Birse, E.L., 1984, Phytocoenonia of Scotland: Additions and Revisions, Aberdeen, Macaulay Institute for Soil Research.

Braun-Blanquet, J., 1952, Les Groupements Végétaux de la France Méditerranéenne, Vaison-la-Romaine, Macabet frères.

Cook, C.D.K., 1966, A monographic study of Ranunculus subgenus Batrachium (DC) A. Gray.: Mitteilung Bototanik Staatssammlung München, v. 6, p. 47-237.

Den Hartog, C., 1963, Enige waterplantengemeenschappen in Zeeland: Gorteria, v. 1, p. 155-164.

Feráková, V., Maglocký, Š., and Marhold, K., 2001, Červený zoznam papradorastov a semenných rastlín Slovenska (December 2001): Ochrana Prírody, v. 20 (suppl.), p. 44-77. Banská Bystrica.

Géhu, J.-M., and Mériaux, J.-L., 1983, Distribution et synécologie des renoncule du sous-genre Batrachium dans le nord de la France: Colloques Phytosociologiques, v. 18, p. 122-166.

Hocquette, M., 1927, Étude sur la végétation et la flore du littoral de la mer du Nord de Nieuport à Sangatte: Archives de Botanique, v. 1, no. 4 , p. $1-179$

Holub, J., and Procházka, F., 2000, Red List of vascular plants of the Czech Republic - 2000: Preslia, v. 72, no. 2-4, p. 187-230.

Horska-Schwarz, S., and Spałek, K., 2008, Charakterystyka wybranych źródeł Śląska Opolskiego [A characteristic of selected springs in Opole Silesia], in Chmielewski, T.J., ed., Struktura i funkcjonowanie systemów krajobrazowych: meta-analizy, modele, teorie i ich zastosowania [Structure and Function of Landscape Systems: Meta-analyses, Models, Theories and Their Applications], Lublin, Wydawnictwo Print 6, Problemy Ekologii Krajobrazu [Problems of Landscape Ecology], no. 21, p. 311-318.

Hultén, E., and Fries, M., 1986, Atlas of North European Vascular Plants: North of the Tropic of Cancer, Königstein, Koeltz Scientific Books.

Husák, Š., and Procházka, F., 1999, Batrachium baudotii (Godron) F.W. Schultz, in Čerovský, J., Feráková, V., Holub, J., Maglocký, S., and Procházka, F., eds., Cervená kniha ohrožených a vzácnych druhov rastlín a živočíchov SR a ČR 5: Vyššie rastliny, Bratislava, Príroda, $53 \mathrm{p}$.

Husák, Š., Slavík, B., and Futák, J., 1982, Batrachium (DC) S.F. Gray, in Futák, J., and Bertová, L., eds., Flóra Slovenska III, Bratislava, Veda, p. $197-214$.

Jasiewicz, A., ed., 1985, Flora Polski 4: Rośliny naczyniowe. Dwuliścienne, Wolnopłatkowe - Dwuokwiatowe [Flora of Poland 4: Vascular Plants, Dicotyledones], 2nd edition, Warszawa-Kraków, PWN-PAN, Instytut Botaniki.

Kaplan, Z., 2005, Batrachium baudotii (Godr.) F. W. Schultz, in Hadinec, J., Lustyk, P., and Procházka, F., eds., Additamenta ad floram Reipublicae Bohemicae. IV. [Additions to the flora of the Czech Republic. IV], Praha, Zprávy České Botanické Společnosti, v. 40, p. $77-149$. 
Kaplan, Z., 2008, Batrachium baudotii (Godr.) F. W. Schultz in Hadinec, J., and Lustyk, P., eds., Additamenta ad floram Reipublicae Bohemicae. VII. [Additions to the flora of the Czech Republic. VII], Praha, Zprávy České Botanické Společnosti, v. 43, p. 251-336.

Király, G., ed., 2007, Vörös Lista: A magyarországi edényes flóra veszélyeztetett fajai. [Red list of the vascular flora of Hungary], Sopron, Saját kiadás, $73 \mathrm{p}$.

Klement, O., 1953, Die Vegetation der Nordseeinsel Wangerooge: Veröffentlichungen aus dem Instituts Meeresforschung, Bremerhaven, v. 2 , p. $279-379$.

Kryza, H., and Kryza, J., 2003, Ocena wpływu ognisk zanieczyszczeń na jakość wód podziemnych w rejonie Strzelec Opolskich [Assessment of the impact of contamination on quality of underground waters within Strzelce Opolskie area]: Współczesne Problemy Hydrogeologii, v. 11, p. 431-439.

Kryza, H., and Kryza, J., 2006, The analytic and model estimation of the direct groundwater inflow to Baltic Sea on the territory of Poland: Geologos, v. 10, p. 153-165.

Kryza, J., and Staśko, S., 2000, Groundwater Flow Rate and Contaminant Migration in Fissure-Karstic Aquifer of Opole Triassic System Southwest Poland: Environmental Geology, v. 39, no. 3-4, p. 384-389. doi: 10.1007/s002540050018.

Kucharski, L., 2007, Flora źródlisk - skład i gatunki wskaźnikowe [Flora of springs - a composition and diagnostic species], in Jokiel, P., Moniewski, P., and Ziułkiewicz, M., eds., Źródła Polski. Wybrane problemy krenologiczne [Springs of Poland. Crenological Selected Problems], Łódź, Wydział Nauk Geograficznych Uniwersytetu Łódzkiego, p. 62-68.

Lindacher, R., 1995, Phanart. Datebank der Gefässpflanzen Mitteleuropas. Erklärung der Kennzahlen, Aufbau und Inhalt, Zurich, Veröffentlichungen des Geobotanischen Institutes der ETH, Stiftung Rübel, no. 125,436 p.

Macioszczyk, A., and Dobrzyński, D., 2002, Hydrogeologia strefy aktywnej wymiany wód podziemnych [Hydrogeology of the area of active exchange of underground waters], Warsaw, Wydawnictwo Naukowe PWN, $448 \mathrm{p}$.

Mirek, Z., Piękoś-Mirkowa, H., Zając, A., and Zając, M., eds., 2002, Flowering Plants and Pteridophytes of Poland - a Checklist: Biodiversity of Poland, v. 1, p. 1-442. Kraków, W. Szafer Insitute of Botany, Polish Academy of Sciences, Biodiversity of Poland no. 1, $442 \mathrm{p}$.

Passarge, H., 1992, Mitteleuropäische Potamogetonetea I: Phytocoenologia, v. 20 , p. $489-527$.

Passarge, H., 1996, Pflanzengesellschaften Nordostdeutschlands. I. Hydro- und Therophytosa, Berlin, J. Cramer, 298 p.
Pott, R., 1995, Die Pflanzengesellschaften Deutschlands, 2 Aufl., Stuttgart, Verl. E. Ulmer, 622 p.

Rodwell, J.S., ed., 1998, British Plant Communities. Vol. 4. Aquatic Communities, Swamps and Tall-Herb Fens, Cambridge University Press, $296 \mathrm{p}$.

Samková, V., 1999, Př́íspěvek k rozšíření některých vzácných a ohrožených druhů rostlin ve východních Čechách [Distribution data on some rare and endangered plant species in the eastern part of the Czech Republic]: Acta musei Reginaehradecensis ser. A, v. 27, p. 19-74.

Schubert, R., Hilbig, W., and Klotz, S., 1995, Bestimmungsbuch der Pflanzengesellschaften Mittel- und Nordostdeutschlands, Heidelberg, Spektrum Akademischer Verlag, 403 p.

Spałek, K., and Horska-Schwarz, S., 2009, Veronico beccabungaeCallitrichetum stagnalis (Oberd. 1957) Müller 1962, a plant association new to Poland - quality of habitat: Acta Societatis Botanicorum Poloniae, v. 78 , no. 4, p. 345-349.

Spałek, K., Proćków, J., Staśko, S., and Horska-Schwarz, S., 2011, Preliminary study of the unusual properties in the habitat of Ranuculetum baudotii in central Europe: Central European Journal of Biology, v.6 no.4, p. 632-638.

Staśko, S., 1984, Charakterystyka hydrogeologiczna wybranych źródeł Śląska Opolskiego [Hydrogeological characteristic of selected springs of Opole Silesia]: Materiały i Studia Opolskie, v. 26, no. 52-53, p. $277-298$.

Staśko, S., 1992, Wody podziemne w weglanowych utworach triasu opolskiego [Underground waters in carbonate formation of Opole Triassic], Prace geologiczno-mineralogiczne, no. 32, 71 p.

Wegener, K.-A., 1991, Pflanzengesellschaften an der Südküste des Greifswalder Boddens: Gleditschia, v. 19, p. 259-288.

Westhoff, V., and den Held, A.J., 1969, Plantengemeenschappen in Nederland, Zutphen, Thieme.

Zając, A., and Zając, M., eds., 2001, Atlas rozmieszczenia roślin naczyniowych w Polsce. Distribution Atlas of Vascular Plants in Poland, Kraków, Laboratory of Computer Chorology, Institute of Botany, Jagiellonian University, $715 \mathrm{p}$.

Zarzycki, K., and Szelagg, Z., 2006, Red list of the vascular plants in Poland. Czerwona lista roślin naczyniowych w Polsce, in Mirek, Z., Zarzycki, K., Wojewoda, W., and Szeląg, Z., eds., Red list of plants and fungi in Poland. Czerwona lista roślin i grzybów Polski, Kraków, W. Szafer Institute of Botany, Polish Academy of Sciences, p. 9-20.

Zarzycki, K., Trzcińska-Tacik, H., Różański, W., Szeląg, Z., Wołek, J., and Korzeniak, U., 2002, Ecological indicator values of vascular plants of Poland, W. Szafer Insitute of Botany, Polish Academy of Sciences, Biodiversity of Poland no. 2, 183 p. 